\title{
Age-related Fiber Order in the Optic Tract of the Ferret ${ }^{1}$
}

\author{
C. WALSH AND R. W. GUILLERY ${ }^{2}$ \\ Department of Pharmacological and Physiological Sciences and the Committee on Neurobiology, The University of Chicago, \\ Chicago, IIIinois 60637
}

\begin{abstract}
In the ferret's optic tract, the position of retinofugal fibers has been related to their relative age by preferentially labeling the oldest fibers. It has been found that fiber order perpendicular to the pial surface represents the sequence of axon arrivals in the optic tract, the fibers furthest from the pia being the oldest.

Immature ferrets, less than 34 days post-conception (E34), were given intravitreal injections of lectin-bound horseradish peroxidase or of ${ }^{3} \mathrm{H}$-amino acids. After survival times of 24 hr or less, the contralateral optic tract was uniformly labeled, whereas with longer survival times unlabeled zones were seen next to the pial border. These unlabeled zones were largest after injections into the youngest animals but were never seen when injections were made after E34, no matter what the survival time. The unlabeled zones were seen in the tracts of animals having unlabeled regions in the periphery of the retina. The unlabeled retinal ganglion cells are interpreted as ganglion cells formed after the injection was made, and unlabeled axons next to the pia in the tract are interpreted as the axons of these youngest cells.

Some irregularities in the layered arrangement of the tract are described, and the fiber order in the tract is contrasted with that in the optic nerve behind the eye. It is shown that tract order is partially independent of order in the intraorbital part of the optic nerve. Between the retina and the optic tract, a sorting of fibers occurs not only in terms of the pattern of decussation, but also in terms of fiber age.
\end{abstract}

It has been shown, for several non-mammalian vertebrate species, that retinofugal fibers are arranged in the optic tract in accordance with age, the oldest fibers lying deepest in the tract (Herrick, 1941, 1942; Gaze and Grant, 1978; Easter et al., 1981; Reh et al., 1983). These animals add ganglion cells sequentially, as rings to the retinal periphery (Hollyfield, 1968; Jacobson, 1976; Johns, 1977), so that the central:peripheral order in the retina is represented in the tract by an order that goes from the deepest to the most superficial parts. That is, the tract can be regarded as a map recording the time of arrival of axons and also as a map that records position of the ganglion cells in the retina.

In the cat, retinal ganglion cclls are not added in such a simple

Received February 4, 1985; Revised April 29, 1985 ;

Accepted May 3, 1985

'We thank Steve Price for help with the figures and Jennifer Hunter for technical assistance. This work was supported by National Institutes of Health Grants RO1 NS-14823 (R. W. G.) and Medical Scientist Training Program Grant 5 T32 GM07281 (C. W.).

${ }^{2}$ To whom reprint requests should be sent, at Department of Human Anatomy, South Parks Road, Oxford, OX1, 3QX, England topographical sequence (Polley et al., 1981; Kliot and Shatz, 1982; Walsh et al., 1983; Walsh and Polley, 1985). Ganglion cells of different size classes have distinct periods of production. The several ganglion cell classes are produced in a series of partially overlapping waves, with each wave having a rough central:peripheral order. The distribution of axons in the adult cat's optic tract (Torrealba et al., 1982) roughly matches this sequence of addition of ganglion cells. The axons deepest in the tract belong to the oldest ganglion cells, and those that lie most superficially arise from the last-born ganglion cells. Thus, since ganglion cell age is related to retinal topography in a complex manner in the cat, the cat's optic tract does not appear to represent a single, simple map of retinal position as in nonmammalian vertebrates. However, the cat's optic tract can still be regarded as a grouping of axons in terms of age, as in other vertebrates.

in order to study the relationship between fiber age and fiber position in the optic tract directly, we have used a technique that labels the oldest retinofugal fibers preferentially (Jacobson, 1976; Scott and Lazar, 1976; Gaze et al., 1979). We have used ferrets instead of cats, because ferrets were more easily obtainable and because the ferret, which is a close relative of the cat (both are members of the order Carnivora) shares with the cat many of the same visual specializations and a closely comparable developmental history (Greiner and Weidman, 1981; Linden et al., 1981; Cucchiaro and Guillery, 1984; Jackson and Amthor, 1984; Schall et al., 1984). Some of these results have been presented before in an abstract (Walsh and Guillery, 1982).

\section{Materials and Methods}

Normally pigmented ferrets of known age were given intravitreal injections of: (1) wheat germ agglutinin conjugated to horseradish peroxidase (WGAHRP) or (2) $\left[{ }^{3} \mathrm{H}\right]$ proline, $\left[{ }^{3} \mathrm{H}\right]$ leucine, $\left[{ }^{3} \mathrm{H}\right]$ fucose, $\left[{ }^{3} \mathrm{H}\right]$ asparagine, or some mixture of these, betwoen the 27th day of gestation (E27) and the third postnatal day (P3), and were allowed to survive for 1 to 30 days (see Table I for details). Other ferrets, which had been given intravitreal injections of tracers and which survived less that $24 \mathrm{hr}$ after the injection (details in Linden et al., 1981; Cucchiaro and Guillery, 1984), were also available for study.

Timed pregnant ferrets (average length of gestation, $41 \pm 1$ days) were purchased from Marshall Research Animals (North Rose, NY). The pregnant jills were anesthetized with sodium pentobarbital supplemented with Xylazine and ketamine. Aseptic precautions with antibiotic prophylaxis were used, and a midline abdominal incision was made to reveal the uterus, which contained 3 to 15 fetuses (average, 9). The head of each fetus could generally be located by transillumination of the uterus or by gentle palpation, although neither technique was reliable with the younger animals. A $1 \%$ solution of lidocaine with 1:1,000,000 epinephrine was applied to the uterine wall, and the head of each felus was exposed by iricising the uterine wall inside the loop of a purse-string suture. This suture was tightened slightly to prevent the body of the fetus from emerging.

After the injections described above had been made through a glass micropipette into one or both eyes (Table I), the fetus was returned to the uterus and the uterine opening was closed by gently tightening and tying 
TABLE I

List of animals used in this study WGA-HRP (Sigma, 0.1 to $1.0 \mu$ l of a $5 \%$ solution) or $\left[{ }^{3} \mathrm{H}\right]$ proline, $\left[{ }^{3} \mathrm{H}\right]$ leucine, $\left[{ }^{3} \mathrm{H}\right]$ fucose, $\left[{ }^{3} \mathrm{H}\right]$ asparagine (New England Nuclear, 50 to $150 \mathrm{Ci} / \mathrm{mmol}, 0.1$ to $1.0 \mu \mathrm{l}$ of a $10 \mu \mathrm{Ci} / \mu$ l solution) were the substances injected. All brains were sectioned horizontally, and all animals received uniocular injections, except as noted. In addition to the material listed here, many ferrets described elsewhere (Cucchiaro and Guillery, 1984) were available. These were given $\left[{ }^{3} \mathrm{H}\right]$ proline, HRP, or WGA-HRP, and then survived 1 day.

\begin{tabular}{|c|c|c|c|}
\hline Animal & $\begin{array}{c}\text { Age at } \\
\text { Injection }\end{array}$ & Substance Injected & $\begin{array}{l}\text { Age at } \\
\text { Sacrifice }\end{array}$ \\
\hline $82-123$ & E27 & WGA.HRP & E28 \\
\hline $82-125$ & E27 & WGA-HRP & E28 \\
\hline $82-154$ & $\mathrm{E} 27$ & WGA-HRP & E32 \\
\hline $82349(1)$ & E27 & WGA-HRP & E39 \\
\hline $82-349(2)$ & E27 & WGA-HRP & E39 \\
\hline $82-349(4)$ & E27 & WGA-HRP & E39 \\
\hline $82-240$ & E27 & ${ }^{3} \mathrm{H}$-Pro, -Leu, -Asn, -fucose ${ }^{a}$ & E40 \\
\hline $82-241$ & E27 & ${ }^{3}$ H-Pro, -Leu, -Asn, -fucose & $\mathrm{E} 40$ \\
\hline $82-242$ & E27 & ${ }^{3} \mathrm{H}$-Pro, -Leu, -Asn, -fucose & $\mathrm{E} 40$ \\
\hline $82-243$ & {$[27$} & ${ }^{3}$ H-Pro, -Leu, -Asn, -fucose & $E 40$ \\
\hline $82-277$ & $\mathrm{E} 27$ & ${ }^{3} \mathrm{H}$-Pro, -Leu, -Asn, -fucose & $\mathrm{P} 23$ \\
\hline $82-278$ & E27 & ${ }^{3} \mathrm{H}$-Pro, -Leu, -Asn, -fucose & P23 \\
\hline $81-322$ & E28 & WGA-HRP & E39 \\
\hline $81-324$ & E28 & WGA-HRP & E39 \\
\hline $81-325$ & E28 & WGA-HRP & {$[39$} \\
\hline $82-138$ & E29 & WGA-HRP & E34 \\
\hline $82-140$ & E29 & WGA-HRP & E34 \\
\hline $82-148$ & E29 & WGA-HRP & E36 \\
\hline $82-149$ & E29 & WGA-HRP & E36 \\
\hline $82 \cdot 151$ & E29 & WGA-HRP & E36 \\
\hline $82 \cdot 184$ & E29 & 3H-Pro, -Leu, -Asn, -fucose & $E 40$ \\
\hline $82-185$ & E29 & ${ }^{3} \mathrm{H}$-Pro, -Leu, -Asn, -fucose & $\mathrm{E} 40$ \\
\hline $82-186$ & E29 & ${ }^{3} \mathrm{H}$-Pro, -Leu, -Asn, -fucose & E40 \\
\hline $82-235$ & E29 & ${ }^{3} \mathrm{H}$-Pro, -Leu, -Asn, -fucose & $\mathrm{P} 22^{b}$ \\
\hline $82-236$ & E29 & ${ }^{3} \mathrm{H}$-Pro, -Leu, -Asrl, -fucose & P22 \\
\hline $81-307$ & E30 & ${ }^{3} \mathrm{H}-$ Fucose & E39 \\
\hline $81-308$ & $\mathrm{E} 30$ & ${ }^{3} \mathrm{H}$-Fucose & E39 \\
\hline $81-310$ & E30 & ${ }^{3} \mathrm{H}$-Fucose & E39 \\
\hline $81-312$ & $\mathrm{E} 30$ & ${ }^{3} \mathrm{H}$-Fucose & E39 \\
\hline $81-317$ & $\mathrm{E} 30$ & ${ }^{3} \mathrm{H}$-Fucose & $\mathrm{E} 39^{b}$ \\
\hline $82 \cdot 72$ & E31 & WGA-HRP & E39 \\
\hline $82-73$ & E31 & WGA-HRP & E39 \\
\hline $81-286$ & E31 & ${ }^{3}$ H-Leu, -Asn & E39 \\
\hline $81-289$ & E31 & ${ }^{3}$ H-Leu, -Asn & E39 \\
\hline $81-290$ & E31 & ${ }^{3} \mathrm{H}$-Leu, -Asn & E39 \\
\hline $81-291$ & E31 & ${ }^{3} \mathrm{H}$-Leu, -Asn & E39 \\
\hline $81-168$ & E31 & ${ }^{3} \mathrm{H}$-Pro & E40 \\
\hline $81-182$ & E31 & ${ }^{3} \mathrm{H}$-Pro & $\mathrm{P} 15^{b}$ \\
\hline $82-69$ & E33 & WGA-HRP & $\mathrm{E} 40$ \\
\hline $82-70$ & E33 & WGA-HRP & $\mathrm{E} 40$ \\
\hline $82-27$ & E34 & WGA-HRP & E39 \\
\hline $82-28$ & E.34 & WGA-HRP & E39 \\
\hline $82-20$ & E35 & WGA-HRP & E39 \\
\hline $82-21$ & E35 & WGA-HRP & E39 \\
\hline $81-104$ & P1 & ${ }^{3} \mathrm{H}-$ Pro & P18 \\
\hline $81-117$ & P3 & ${ }^{3} \mathrm{H}$-Fucose & P19 \\
\hline $81-118$ & P3 & ${ }^{3} \mathrm{H}-\mathrm{Pro}$ & $\mathrm{P} 19^{c}$ \\
\hline F10D & adult & ${ }^{3} \mathrm{H}-$ Pro & adult ${ }^{d}$ \\
\hline
\end{tabular}

${ }^{2}{ }^{3} \mathrm{H}$-Pro, $\left[{ }^{3} \mathrm{H}\right]$ proline: ${ }^{3} \mathrm{H}$-Leu, $\left[{ }^{3} \mathrm{H}\right]$ leucine; ${ }^{3} \mathrm{H}$-Asn, $\left[{ }^{3} \mathrm{H}\right]$ asparagine

${ }^{b}$ Bilateral injections.

${ }^{c}$ Sectioned frontally.

${ }^{\circ}$ Killed 14 days after injection; sectioned parasagittally.

the suture. In each female several of the young were prepared in this way before the abdominal incision was closed and the jill was allowed to recover. One to 12 days later the jill was deeply anesthetized. The animals which had received tracers were identified by the presence of sutures in the overlying uterine wall, and these animals were removed and prepared as described below.

The ferrets that had been given WGA-HRP were perfused through the heart with saline followed by $4 \%$ glutaraldehyde in $0.1 \mathrm{M}$ phosphate buffer at $\mathrm{pH}$ 7.4. The brain was dissected free, embedded in a gelatin/albumen mixture and immersed overnight in $30 \%$ sucrose in phosphate buffer Horizontal $30-\mu \mathrm{m}$ frozen sections were cut so that the fibers of the optic tract were cut approximately transversely. For some of the animals the eyes and optic nerves were embedded separately and frozen $30-\mu \mathrm{m}$ sections were cut in the frontal plane. The sections were processed for HRP histochemistry by the tetramethyl benzidine method (Mesulam, 1984), mounted on gelatincoated slides, and counterstained with a $0.01 \%$ neutral red solution at $\mathrm{pH}$ 3.3

The ferrets that had been given titriated tracers were decapitated, the skull was opened, and then the entire head was fixed in Carnoy's solution The skull and jaw were trimmed, the bone was decalcified in $10 \%$ nitric acid in $80 \%$ ethanol, and the entire head was then dehydrated in ethanol, cleared, and embedded in paraffin. Horizontal $10-\mu \mathrm{m}$ sections were cut, and a 1-in-5 series was processed with standard autoradiographic techniques (Rogers, 1979) and counterstained with cresyl violet.

Sume of the fetal lerrets that had been given injections of tritiated compounds were removed by Caesarian section on E40 and then were transferred to another, lactating jill. These kits survived up to 3 weeks postnatally, at which time they were anesthetized with ether and perfused through the heart with $10 \%$ formol saline or else were decapitated and the brain then fixed by immersion in Carnoy's solution. Three ferrets which had been given injections as neonates (see Table I) also survived for up to 15 days. In addition, one adult ferret, given an intravitreal injection of [ $\left.{ }^{3} \mathrm{H}\right]$ proline and allowed to survive for 14 days, was available for autoradiographic study. A number of semithin plastic sections cut perpendicular to the fibers of the tract were also available. These were taken from blocks of the adult tract, which had been post-fixed in osmium tetroxide and embedded in Durcupan.

\section{Results}

The fiber arrangement in the ferret's optic tract. The fibers in the optic tract of the adult ferret are arranged essentially like those of the cat (Guillery et al., 1982). In a transverse section one sees a rostral and medial region that is made up largely of medium caliber axons, and a more lateral region in which large axons are prominent, although not numerous. A narrow band near the pia contains a predominance of extremely fine fibers. The autoradiographs and HRP sections obtained after short survivals show that, at all ages, from E28 to adult, the ferret's optic tract also shows a localization of the crossed and uncrossed fibers comparable to that seen in the cat (Torrealba et al., 1982). Whereas the crossed fibers are distributed throughout the cross-sectional area of the tract (as shown in Fig. 1 for E27-E28), uncrossed fibers are absent from the medial, deepest portion of the tract and are scattered and greatly outnumbered by crossed fibers in the lateral, subpial margins (see Linden et al., 1981; Cucchiaro and Guillery, 1984, for descriptions of the oider animals). A fiber bundle that lies posterior and adjacent to the optic tract is never labeled in any of our material. This bundle (see Figs. 1 to $3,5,6$, and 8 , asterisk ) has been interpreted as the supraoptic commissures (Linden et al., 1981; Cucchiaro and Guillery, 1984)

The labeling of retinofugal fibers seen after survival times of 5 days or more. Injections of WGA-HRP or ${ }^{3} \mathrm{H}$-amino acids into an eye of a fetus younger than E34 produced a nonuniform labeling of the contralateral optic tract it the survival time after the injection was greater than 5 days. Axons near the pial surface were unstained, the size of the unstained region being larger the younger the animal was at the time of the injection (see below and see Fig. 4). This was in contrast to the relatively uniform labeling seen with shorter survival times (above and Fig. 1) or when injections were made after E34. For these older animals, prenatal or postnatal, the labeling was always relatively uniform, no matter what the survival (Fig. 8).

At first we used several different tracers, in order to determine whether the pattern of axonal labeling was related to some particular property of the tracer. However, there were no significant differences seen in the labeling patterns produced by different substances, given the same age and survival times. The high sensitivity and low 


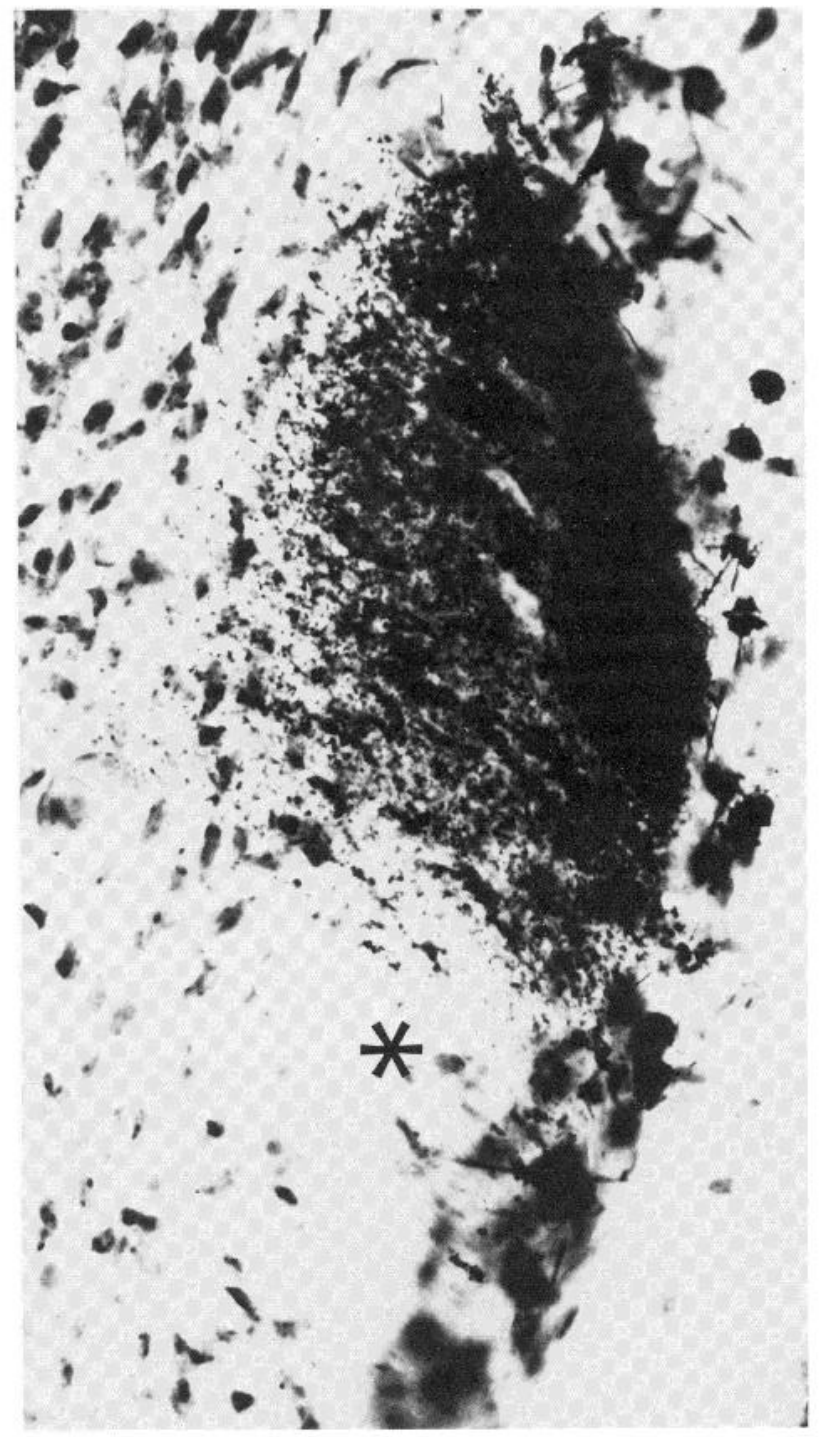

Figure 1. A horizontal section through the optic tract of a ferret contralateral to an injection of WGA-HRP given on E27, with survival to E28. This horizontal section cuts the optic axons approximately transversely. HRP reaction product covers the entire cross-section of the optic tract. An unlabeled fiber bundle posterior to the optic tract (asterisk) represents the supraoptic commissures. The retina and optic nerve of this animal were also sectioned, and showed a similar even distribution of HRP reaction product. Medial is to the left, and rostral is up. Magnification $\times 700$.

background labeling obtained with the WGA-HRP made it most suitable for showing the nonuniform labeling after the shorter survivals (5 to 12 days), whereas the relatively gradual degradation of the ${ }^{3} \mathrm{H}$ derivatives made these particularly suitable for the longer survival times (greater than 12 days).

Each of the 12 ferrets given WGA-HRP between E27 and E29, and surviving 5 to 12 days thereafter (see Table I), showed heavy label in the contralateral optic tract, but only within its medial, deepest regions. The lateral parts of the contralateral optic tract, near the pial surface, were completely unlabeled in 11 of these animals (Fig. 2) and were only lightly labeled in the 12th animal (not illustrated), in which the deeper labeling was particularly heavy. In the ipsilateral tract, label was either absent (6 animals) or was lightly scattered in the medial third of the tract, although it never reached the most medial border of the tract, which represents the pure crossed component.

The selective labeling produced by the autoradiographic method was similar. Four animals given injections on E27 and killed on E40 (see Table I) showed heavy label in the deepest, medial portions of the contralateral tract, with lighter label laterally near the pial border (see Figs. 3 and 4). Two animals given injections on E29 and also killed on E40 showed a similar pattern of labeling, although a larger fraction of the contralateral tract was marked by heavy label (Fig. 4). The ipsilateral tract showed very light label in all of the animals and this, again, was limited to the posteromedial portions of the tract, leaving the most medial margin, the pure crossed component, unlabeled. A third animal given an injection on E29 and killed on E40 showed much higher levels of label throughout the visual system, and here the label covered most of the cross-sectional area of the contralateral tract except for a more lightly labeled band just beneath the pia. The different pattern of labeling seen in this animal may represent a heavier dose of tritium or it may represent an animal that was developmentally more advanced than its littermates (see below).

Animals with longer survival times after the injection also showed the differential distribution of the label. Four ferrets that were given radioactive tracers on E27 (two animals) and E29 (two animals) survived until P23 and P22, respectively (see Table I). At this postnatal stage the retinofugal projections have an essentially adult distribution (Linden et al., 1981), the tract has increased substantially in size, and its shape as seen in horizontal sections has altered. Figure 5, from an animal given an injection on E27, shows that in the contralateral tract the label is largely confined to the posterior and medial borders. Injections given on E29 labeled a somewhat

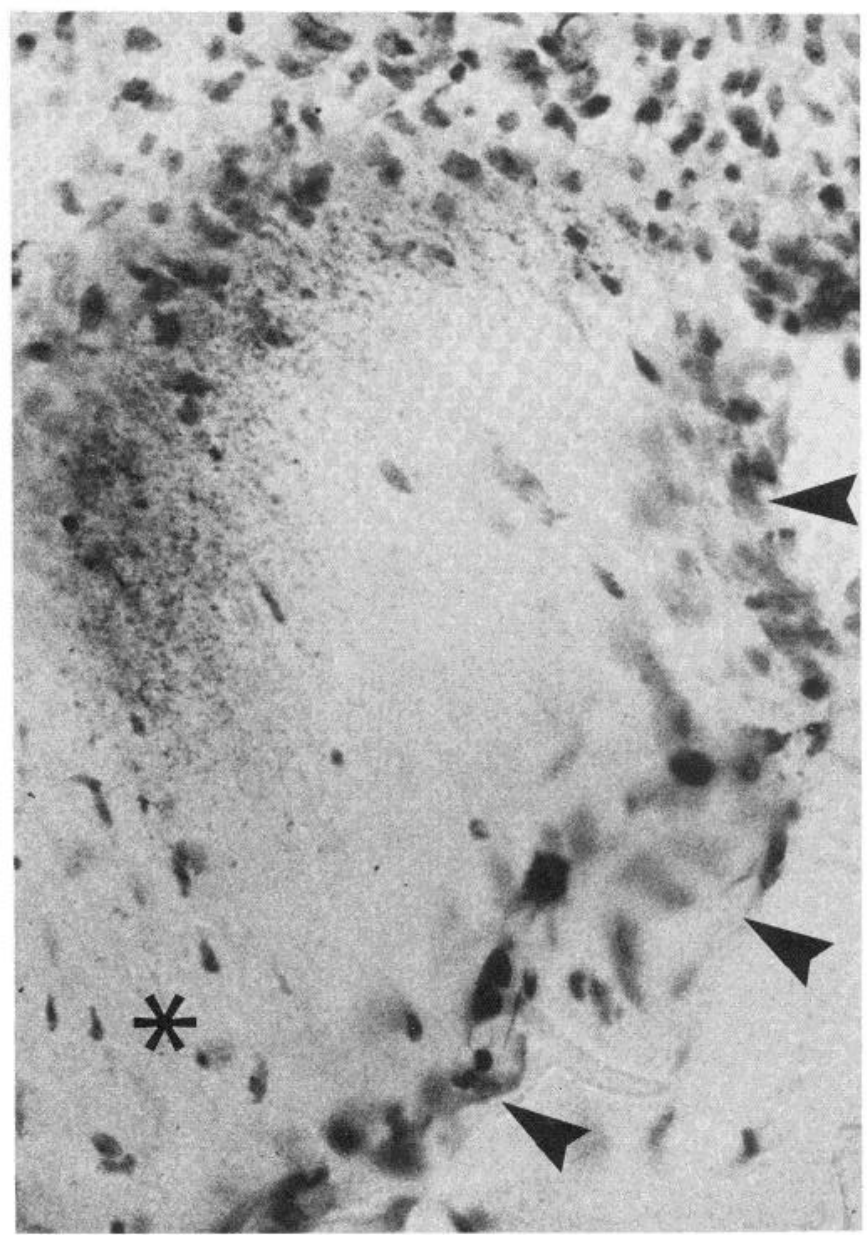

Figure 2. A horizontal section through the optic tract contralateral to an intravitreal injection of WGA.HRP made on E29 in a ferret which survived 5 days, until E34. Orientation is as in Figure 1. Note that after the longer survival time, HRP reaction product is now limited to the deepest part of the tract, whereas a large region near the pial surface (arrowheads) is free of label. The supraoptic commissures (asterisk) are unlabeled. Magnification $\times 630$. 


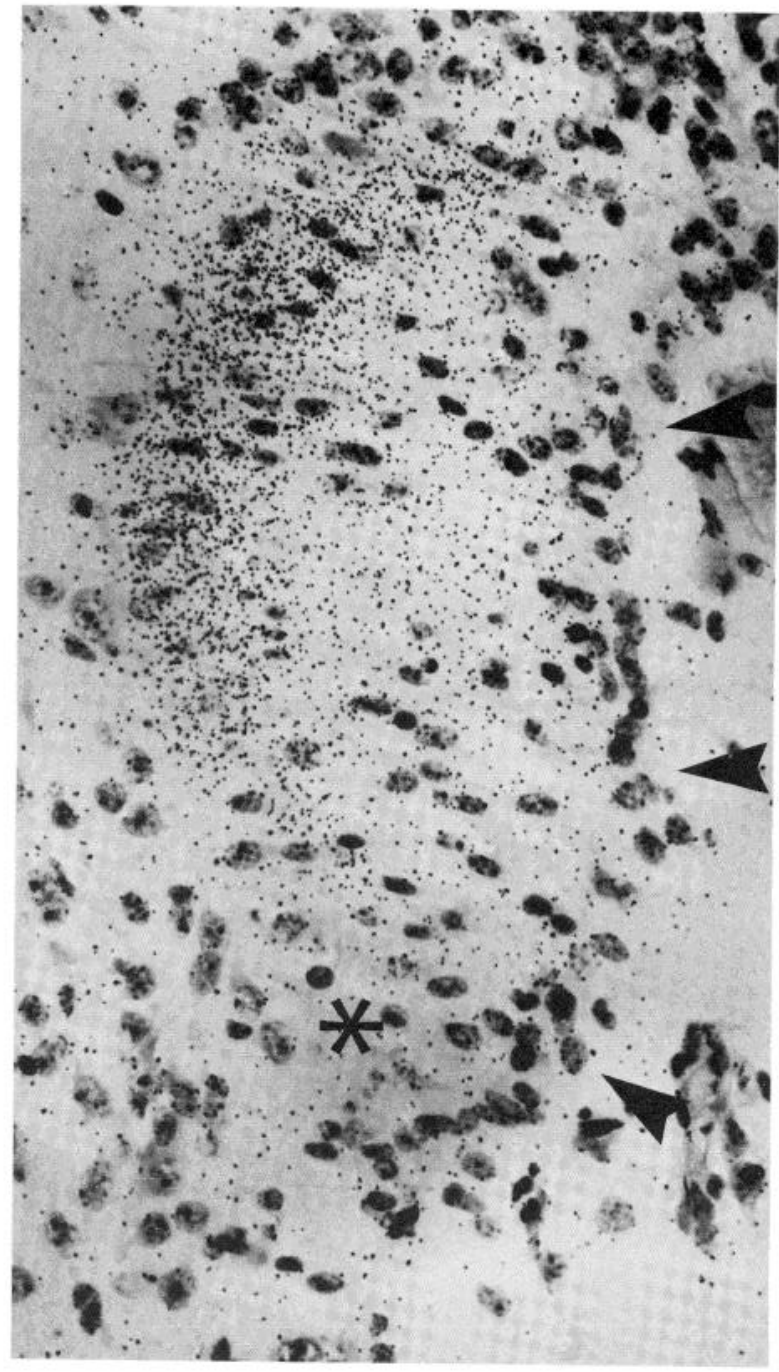

Figure 3. A horizontal section through the optic tract contralateral to an intravitreal injection of $\left[{ }^{3} \mathrm{H}\right]$ leucine, $\left[{ }^{3} \mathrm{H}\right]$ proline, $\left[{ }^{3} \mathrm{H}\right]$ fucose, and $\left[{ }^{3} \mathrm{H}\right]$ asparagine on E27, in a ferret which survived until E40. The heaviest label is seen in the deepest parts of the tract, whereas a large region containing lighter label lies adjacent to the pia (arrowheads). The asterisk indicates the region of the supraoptic commissures. Orientation is as in Figure 1. Magnification $\times 380$.

larger fraction of the tract. No ipsilateral label was seen in any of these animals with long postnatal survival times.

Injections made in older animals labeled relatively more of the contralateral tract. Five ferrets given $\left[{ }^{3} \mathrm{H}\right]$ fucose on E30 and killed on E39 showed dense label throughout most of the contralateral tract, with patches of lighter label in the anterolateral corner (Fig. 4). One animal given bilateral injections on E30 and killed on E39 showed the same pattern of labeling in both tracts. In the ipsilateral tract of the animals given unilateral injections there was a crescent of label deep in the tract, and this ipsilateral label included the anteromedial parts of the tract (Fig. 4) which had been left unlabeled by the earlier injections.

Injections given on E31 produced heavy labeling over most of the contralateral optic tract, except for a rim just beneath the pia. Most of the animals given injections on E31 and killed on E39 or E40 (see Table I) showed a lightly labeled "notch" extending anteromedially from the posterolateral corner of the tract (Figs. 4, 6, and 7). This pattern, when it was present, was seen throughout the length of the contralateral tract (Fig. 7). Three of the animals given $\left[{ }^{3} \mathrm{H}\right]$ proline on E31 showed no obvious notch. Two (one killed on E40, one killed on P15) showed lighter label nearest the pia, whereas the third (killed on E39) showed uniform label throughout the whole cross-sectional area of the tract and unusually heavy labeling throughout the visual system.

Of the two animals given injections on E33 and killed on E40 (see Table I), one showed a small unlabeled notch in the contralateral tract like that described above, whereas the other showed relatively light labeling only. All injections given after E33 produced label all across the cross-sectional area of the contralateral optic tract, no matter what substance was used or what the length of the survival period (Fig. 8).

\section{injection on}

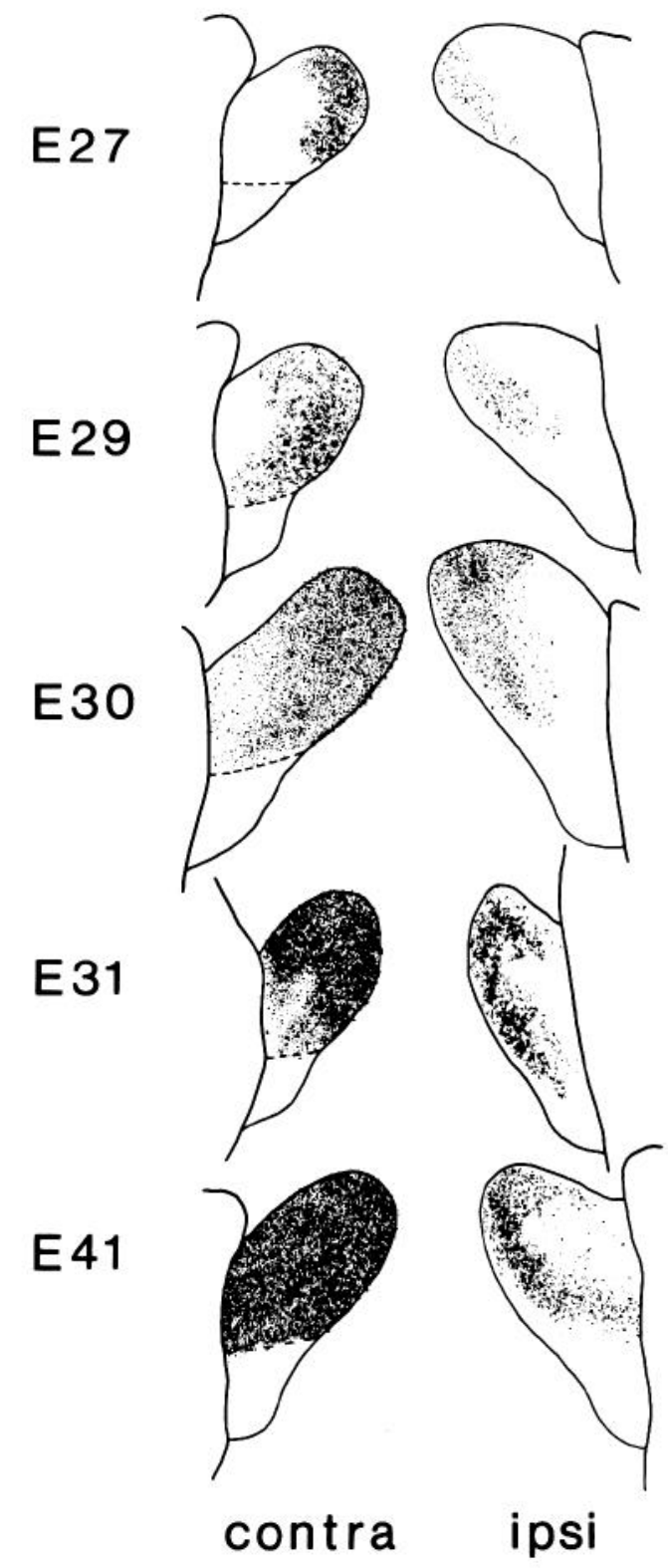

Figure 4. A series of drawings of the ipsilateral and contralateral optic tracts of fetal ferrets given intravitreal injections of radioactive tracers on E27, E29, E30, and E31, and allowed to survive until E39 or E40. For comparison, a ferret given $\left[{ }^{3} \mathrm{H}\right]$ proline at E41 and killed 1 day later (bottom) is included. The dashed line in the contralateral tract indicates the border of the supraoptic commissures. Injections at successively older ages labeled a progressively larger fraction of the retinal fibers in each tract. Rostral is up for each drawing. For further discussion see the text. Magnification $\times 75$. 


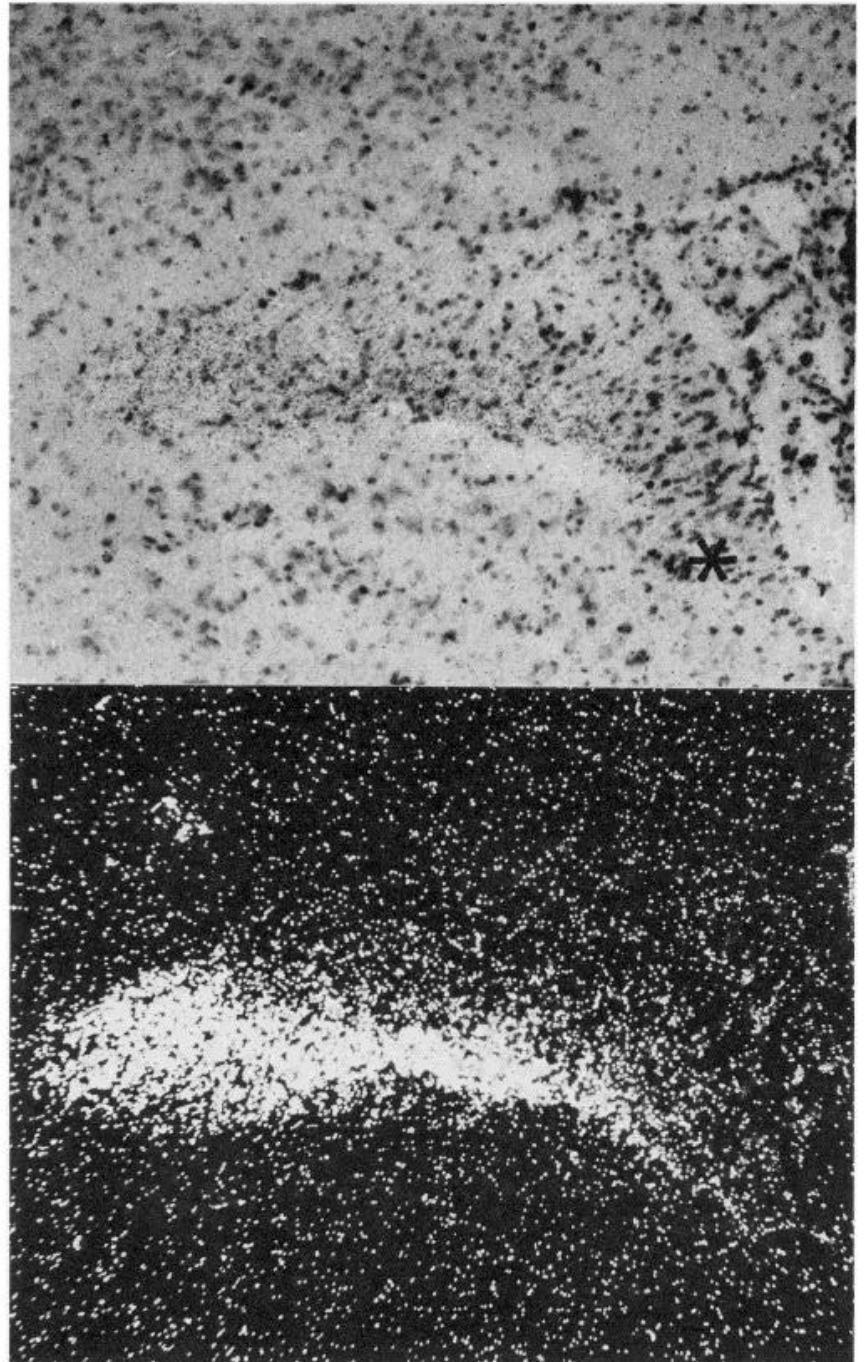

Figure 5. Matching light- and darkfield photomicrographs showing an autoradiograph of a section through the optic tract contralateral to an intravitreal injection of $\left[{ }^{3} \mathrm{H}\right]$ leucine, $\left[{ }^{3} \mathrm{H}\right]$ asparagine, $\left[{ }^{3} \mathrm{H}\right]$ fucose, and $\left[{ }^{3} \mathrm{H}\right]$ proline at E27. This animal, a littermate of the animal shown in Figure 3, survived an additional 3 weeks, until P23. By this time the retinofugal projection is mainly adult-like (Linden et al., 1981). Note that the size and shape of the optic tract have changed substantially compared to the younger animals, and the heaviest label now occupies the posteromedial extreme of the tract. In both photographs, rostral is up, medial is to the left, and the pial margin is to the right, as in Figures 1 to 3 . The supraoptic commissures at this age are less conspicuous and now lie posterior to the optic tract, near the pial surface (asterisk). Magnification $\times 120$.

The labeling of the retina and optic nerve. In order to define the relationship between the partial labeling of the optic tract and the distribution of label in the eye, we have studied the retinae and optic nerves of some of the animals in which the optic tract was incompletely labeled. In most animals sections of the retina were prepared and the retina looked normal, demonstrating that the partial label in the optic tract was not due to retinal damage. In 15 animals the retinae were reacted for HRP in order to demonstrate not only the condition of the retina but also the part of the retina labeled with HRP. Figure 9 shows the retina from one of these animals in which the retina was exposed to WGA-HRP on E29 and fixed on E36. The retinal structure was like that of the normal retina on the other side, which was treated identically. It was also like that of age-matched control animals, indicating that the WGA-HRP injections had not significantly affected the development of the retina.
In the retina shown in Figure 9, the HRP reaction product was limited to the ganglion cell and inner plexiform layers, was lighter in peripheral than in central retina, and was totally absent near the ora serrata, in the region known to contain the youngest ganglion cells in other mammalian retinae (Sidman, 1961; Walsh et al., 1983; Walsh and Polley, 1985). A similar pattern of label was seen in seven other retinae treated similarly. Four retinae taken from animals with very long survival times (9 to 12 days) showed very light labeling, although labeling in the tract was quite distinct. We interpret this nonuniform retinal label as indicating that the newest ganglion cells developed after the injection was made and that the unlabeled axons in the tract took their origin from these unlabeled cells. In contrast to this, three animals with a uniform distribution of label in the contralateral optic tract also showed a uniform retinal labeling.

The optic nerves of five of the animals given injections of WGAHRP on E27 or E29 and allowed to survive 5 to 12 days postoperatively (81-349(2), 82-154, 82-138, 82-148, and 82-149) were sectioned in order to compare the partial labeling in the optic tract with

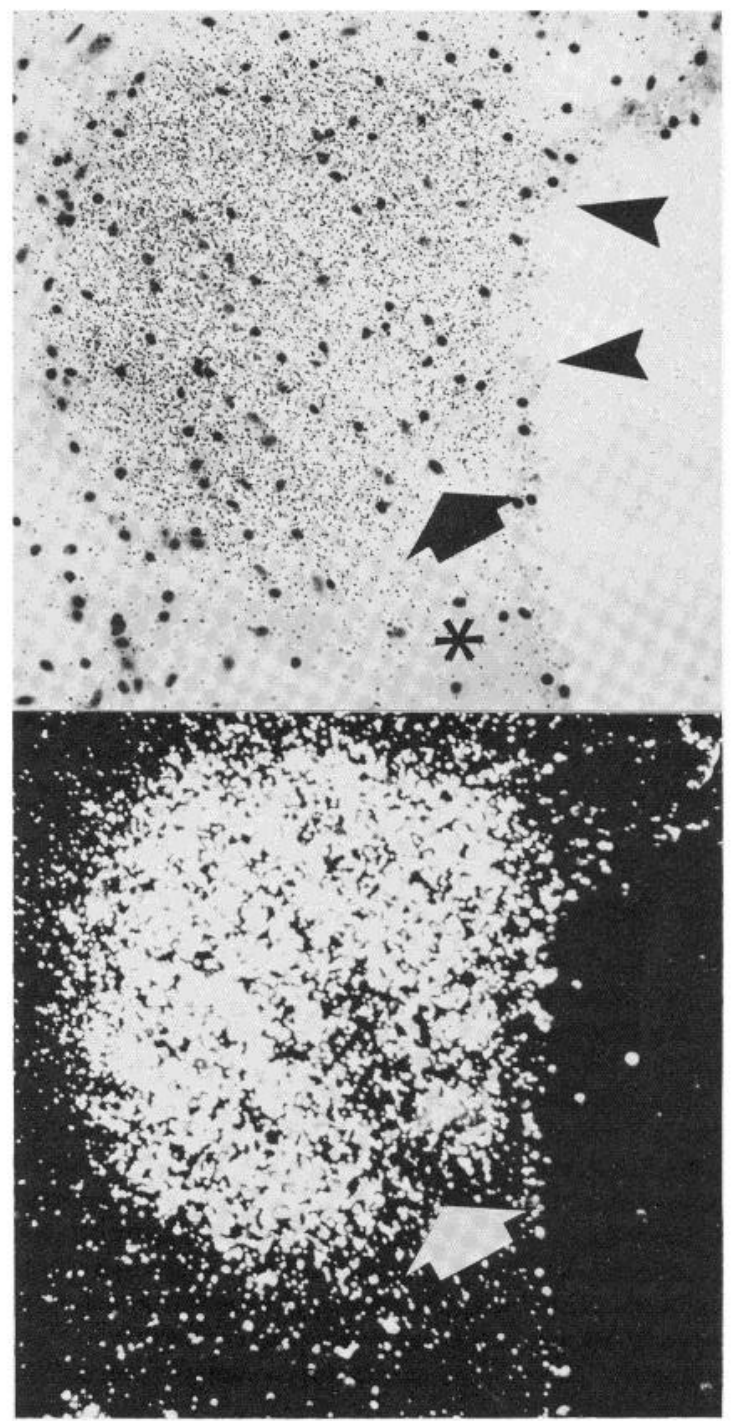

Figure 6. Matching light- and darkfield photomicrographs showing an autoradiograph of a section through the optic tract contralateral to an intravitreal injection of $\left[{ }^{3} \mathrm{H}\right]$ leucine and $\left[{ }^{3} \mathrm{H}\right]$ asparagine made on $\mathrm{E} 31$, in an animal that survived until E39. The label covers the entire tract except for a faint notch in the posterolateral corner of the tract (arrow) and a lightly labeled rim along the pial surface of the tract (arrowheads). Compare with Figure 7. The unlabeled supraoptic commissures are indicated by the asterisk. Orientation is as in Figure 1. Magnification $\times 290$ 


\section{injection on E31}

\section{survived until E39}
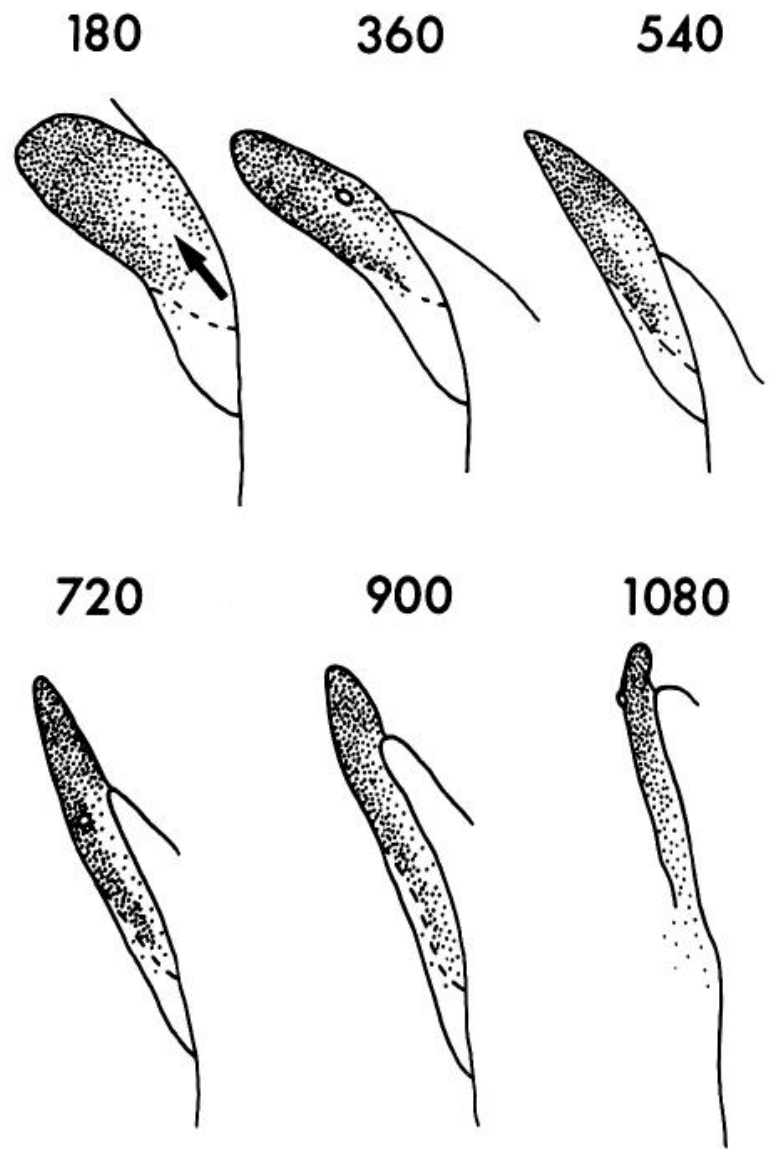

Figure 7. Drawings taken from the optic tract contralateral to an intravitreal injection of WGA-HRP on E31, in an animal which survived until E39. Drawings were made from a section $180 \mu \mathrm{m}$ above the chiasm, and then every 180 $\mu \mathrm{m}$ dorsally until the tract began to break up as it entered the ventral lateral geniculate nucleus. Note that the distinctive pattern of label (with an unlabeled "notch" indicated by an arrow) is maintained along most of the length of the tract. Lighter labeling is always found adjacent to the pial surface, despite the fact that the overall shape of the tract changes considerably along its length. The outlines of the tract are shown by solid lines. Several blood vessels penetrated the tract but bore no consistent relationship to the pattern of label in the tract; two are indicated with solid outlines. The dashed line represents the approximate boundary between the optic tract and the supraoptic commissures. In all drawings, anterior is up and medial is to the left, as in Figure 1. Magnification $\times 70$.

the distribution of label in the nerve. Each nerve also showed a nonuniform distribution of label. Although the segregation of labeled and unlabeled zones was not as sharp as the segregation of labeled and unlabeled zones in the tract, it was possible to see that the unlabeled regions became clearer as the nerve approached the tract. However, since the appropriate section plane for studying the nerve is perpendicular to that suitable for the tract, this limited material was inadequate for a complete description of the distribution of labeled and unlabeled fibers in the nerve. Other animals given injections at E27 and killed $20 \mathrm{hr}$ later showed uniform labeling across the optic nerve on the side of the injection.

\section{Discussion}

Our results show that intravitreal injections of tritiated amino acids or WGA-HRP into immature ferrets (younger than E34) produce a uniform labeling of retinofugal fibers after short survival times (less than $24 \mathrm{hr}$ ) but produce a selective labeling of only the deepest fibers in the optic tract with longer survival times (more than 5 days). Injections made after the 34th intrauterine day produce a uniform labeling even with long survival times. Our interpretation is that the more lightly labeled or unlabeled fibers, which lie close to the pial surface of the tract, are the youngest fibers, arising from cells formed after the administration of the marker. This intepretation is supported by several independent lines of evidence.

Technical considerations. Since intravitreal injections of $\left[{ }^{3} \mathrm{H}\right]$ proline or WGA-HRP (or HRP alone) produce a relatively uniform labeling across the contralateral optic tract when short survival times are used (Cucchiaro and Guillery, 1984), the selective label seen consistently after longer survival times cannot be produced by a selective uptake or a selective initial transport of the label. The facts that (1) the unlabeled zone always occupies the same, outer, portion of the tract, (2) this zone is seen with two quite different types of anterograde marker (HRP and tritiated amino acids), and (3) the zone is seen after early but not after late injections all suggest that we are seeing the effects of a normal developmental process, not those of a technical artifact, which might be expected to produce occasional examples of patchy labeling.

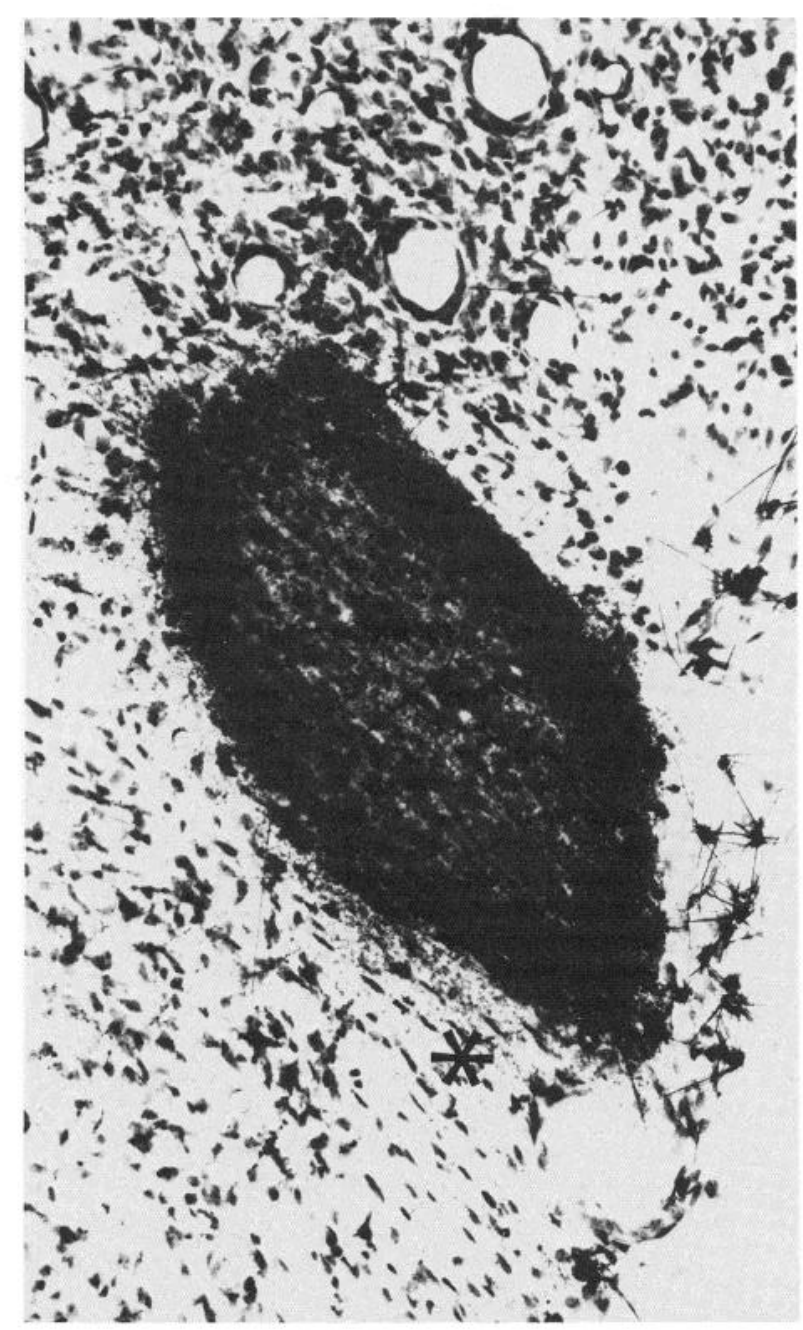

Figure 8. A section through the optic tract contralateral to an intravitreal injection of WGA-HRP made on E34, in a ferret that survived until E39. At age E35 in a cat, ganglion cell production is nearly complete (Walsh et al., 1983; Walsh and Polley, 1985). Note that, even with a long survival time, injections at this relatively late stage produced uniform label of the crossed axons in the optic tract, extending densely up to the pial surface. The supraoptic commissures are indicated by an asterisk. Orientation is as in Figure 1. Magnification $\times 330$. 


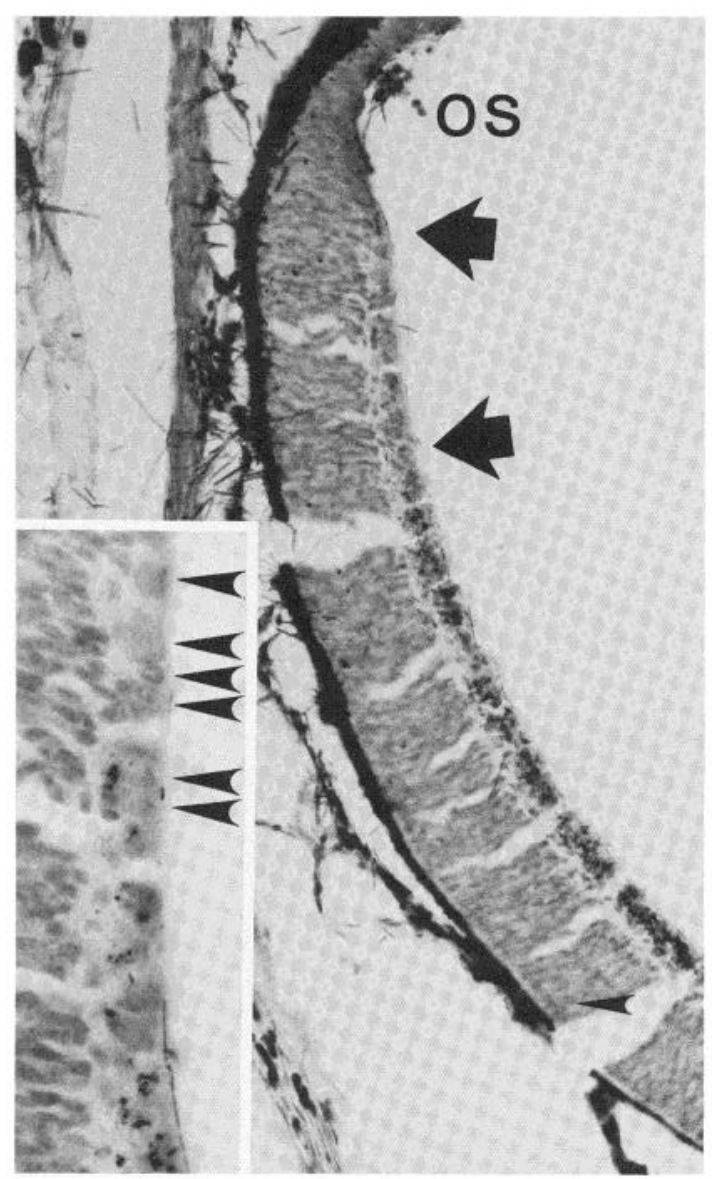

Figure 9. A section through the retina of a ferret given WGA-HRP on E29 and killed 7 days later, on E36. The optic tract of this animal showed HRP reaction product limited to its deepest portion, as in Figure 2. In the retina, HRP reaction product is limited to the ganglion cell and inner plexiform layers, and is heaviest in central retina (not shown), becoming progressively lighter in peripheral retina. Near the ora serrata (os), the reaction product is absent altogether. Similar lightly labeled and unlabeled regions were seen throughout the peripheral retina of this animal and of all other animals treated similarly. Magnification $\times 192$. The inset shows the region between the arrows at higher magnification $(\times 500)$, with arrowheads indicating nuclei of unlabeled cells in the ganglion cell layer.

It has been demonstrated for other species that most of the cellular uptake of $\left[{ }^{3} \mathrm{H}\right]$ leucine or $\left[{ }^{3} \mathrm{H}\right]$ fucose occurs within hours of an intravitreal injection (Karlsson and Sjöstrand, 1971, 1972; Schonbach and Cuenod, 1971; Sjöstrand et al., 1973; Goodrum et al., 1979), whereas most of the radioactivity incorporated into the axons is lost much more gradually, over days or weeks (Goodrum et al., 1979). The younger ganglion cells that are formed after the injected label has been cleared are exposed to lower levels of the marker than their older fellows and they are thus relatively lightly labeled or unlabeled whereas the marker incorporated into the older axons persists.

A comparable argument applies to the incorporation and transport of HRP. Uptake has been shown, in several different systems, to be limited to less than $18 \mathrm{hr}$ (LaVail and LaVail, 1974; Vanegas et al., 1978; Mesulam, 1984), whereas the label in the pathways persists for 7 to 14 days after the injection (Mesulam, 1984).

An experimental approach similar to the one we have used has previously been exploited by Scott and Lazar (1976), Jacobson (1977), and Gaze et al. (1979). They used Xenopus tadpoles, in which the retina grows by the addition of peripheral rings, and they showed that, 2 to 8 weeks following an intraocular injection of $\left[{ }^{3} \mathrm{H}\right]$ proline, this autoradiographic label is limited to the older ganglion cells of the central retina, and to their axons, whereas newer ganglion cells in the retinal periphery remain unlabeled. $\left[{ }^{3} \mathrm{H}\right]$ Thymidine administered when the $\left[{ }^{3} \mathrm{H}\right]$ proline is given is heavily incorporated into nuclei undergoing their final division at this time, and these cells can be shown forming a border between the retinal zones labeled with proline and those that are unlabeled. In the tectum it was shown that the proline selectively labels the older but not the newer ganglion cell axons.

Some of the observations reported here support the view that the injected labels are seen in older but not in newer cells. Most strikingly, the unlabeled patches in the contralateral tract are largest when injections are made into the youngest animals, and when the greatest proportion of retinofugal axons have yet to develop. These unlabeled patches are progressively smaller as injections are made later in development and are not seen at all when the injections are made late, after the 34th intrauterine day. Furthermore, the interpretation being offered fits earlier accounts of the relationship that can be established between fiber distributions in the cat's optic tract and the birth dates of retinal ganglion cells (Torrealba et al., 1982; Walsh and Polley, 1985)

Although the dates of ganglion cell formation have not been defined in the ferret, the stage at which the selective labeling of the contralateral tract ceases probably corresponds to the stage by which the majority of the retinal ganglion cells are postmitotic. The evidence for this is obtained from the cat in which many of the major landmarks of early visual development are seen at the same times as in ferrets (Greiner and Weidman, 1980, 1981; Linden et al., 1981; Shatz, 1983; Cucchiaro and Guillery, 1984). In the cat the majority of ganglion cells are postmitotic by E35 (Kliot and Shatz, 1982; Walsh et al., 1983), so that it is reasonable to conclude that the period of selective tract labeling ends roughly when ganglion cell production ends in the ferret.

We have shown that unlabeled zones seen in the optic tract after injections of WGA-HRP are always accompanied by lighter label in the peripheral retina than in the central retina. Although the mammalian retina does not show a sharp topographic segregation of newer from older ganglion cells, there is a tendency for newer ganglion cells to predominate in the peripheral retina (Sidman, 1961; Polley et al., 1981; Kliot and Shatz, 1982; Walsh et al., 1983; Walsh and Polley, 1985; C. Walsh and R. W. Guillery, unpublished observation on ferrets). The observations on the distribution of WGA-HRP thus support the conclusion that newer ganglion cells and their axons tend to be more lightly labeled after early injections.

There is strong evidence from several mammalian species that a significant number of retinal ganglion cells and their axons are lost during development (Sengelaub and Finlay, 1981; Cunningham et al., 1982; $\mathrm{Ng}$ and Stone, 1982; Rakic and Riley, 1983; Cucchiaro, 1984). Insofar as our method shows the selective labeling of the contralateral tract at stages that probably precede the major wave of cell loss (E39) and also at later stages (P23), one can conclude that the cell loss does not affect the topographic order established in the optic tract. However, it should be noted that our method does not demonstrate any of this cell loss and that relatively small changes in fiber distributions that might be caused by such a cell loss would not be seen with our methods.

The grouping of axons by age in the ferret's optic nerve and tract. The evidence we have presented suggests that in the formation of the ferret's optic tract, new axons are added mainly near the pial surface, displacing older axons toward the deeper parts of the tract as development proceeds. This resembles the situation in frogs and fish (Herrick, 1941, 1942; Reh et al., 1983; Rusoff, 1984) except that, in these, the addition of new, subpial fiber layers continues throughout life, whereas the process is completed prenatally in the ferret, and in its later stages, does not occur evenly all along the pial surface. In ferrets the oldest fibers lie posteriorly and medially in the tract (Fig. 5). The younger fibers tend to lie anteriorly, and some of the youngest form a notch in the posterolateral part of the tract.

The observation that new axons tend to grow near the pial surface was made by His (1904) for the human spinal cord and has subsequently been made for other regions and other species (e.g., 
Herrick, 1941, 1942; Nordlander and Singer, 1982; Taylor and Roberts, 1983; Easter et al., 1984). The details of this rolationship are still not well defined. In some regions the axons are separated from the basal lamina by a row of glial end-feet (Rager, 1980; Krayanek and Goldberg, 1981), whereas in others the growing fibers insinuate themselves between the glial end-feet, contacting the basal lamina itself (Nordlander and Singer, 1982; Scholes and Maggs, 1983; Taylor and Roberts, 1983; Easter et al., 1984). The extent to which components specifically associated with the basal lamina attract axons or enhance axonal adherence (Akers et al., 1981; Letourneau, 1982; Rogers et al., 1983) in these different situations remains to be defined.

There are situations in which growing axons show no particular relation to the pial surfaces (e.g., Ramón y Cajal, 1960; Skoff and Hamburger, 1974), and one can anticipate that axonal pathways taking complex central routes cannot depend entirely upon markers associated with the basal lamina. Preliminary observations of the mammalian optic nerve have shown that growth cones are not restricted to the region of the basal lamina or of the subpial end-feet (Williams and Rakic, 1984a, b; E. Carpenter and R. W. Guillery, unpublished observations of fetal mice), but comparable observations of the mammalian optic tract have yet to be made.

A comparison of the adult structure of the mammalian optic nerve and tract demonstrates that a major change in fiber order occurs belween the nerve and the tract. Whereas axons are grouped according to size in the tract (Bishop et al., 1953; Bishop and Clare, 1955: Guillery et al., 1982: Mastronarde, 1984), this same arrangement is not seen in the intraorbital part of the nerve (Van Crevel and Verhaart, 1963; Donovan, 1967; Hughes and Wässle, 1976; Williams and Chalupa, 1983). Although there is some clinical evidence for a precise retinotopic arrangement of fibers in the optic nerve (Polyak, 1957), experimental studies of cats, rabbits, rats, and monkeys have all shown a rather poor retinotopic order in the nerve (Brouwer et al., 1923; Brouwer and Zeeman, 1926; Lashley, 1934; Hoyt and Luis, 1962; Horton et al., 1979; Bunl and Lund, 1982). The precise order of the fibers in the mammalian optic nerve remains to be defined.

The region of the optic chiasm can now be regarded as of particular interest because the retinofugal fibers are sorted not only in terms of their laterality (ipsilateral fibers being guided along one pathway, contralateral fibers along another), but are also sorted in terms of their age. ${ }^{3}$ We do not know how these two sorting processes are related to one another, or to the final formation of several separate retinotopically organized maps in the visual relays. However, the pattern of decussation also changes during development as the temporal order of the tract is laid down. The youngest ganglion cells have a line of decussation that is less sharp than that of the older ganglion cells, and this line is also shifted progressively further into the temporal retina as development proceeds (Walsh et al., 1983; Walsh and Polley, 1985).

The formation and the arrangement of the several separate terminal maps may depend to some extent upon the temporal sorting that occurs between the optic nerve and the optic tract. This can produce some rough pre-sorting of the different fiber classes, and fibers lying deepest in the tract also pass to the deepest geniculate and tectal layers (Torrealba et al., 1982). The temporal sorting can also produce some of the order seen in each of the individual maps, but, as has been pointed out by Reh et al. (1983) for Rana, a grouping of fibers by age alone can account for only one dimension of a two-dimensional map. One needs to find other explanations for understanding how fibers from the superior and inferior retina become separately mapped. The change in the relationships between fibers that occurs as fibers pass from the eye to the tract must depend upon some change in the glial or neuroepithelial environment characterizing this region. The issue merits study because it relates

\footnotetext{
${ }^{3}$ Since this discussion was written it has been shown (C. Walsh, manuscript submitted) that the major age-related reorganization occurs within the intracranial segment of the optic nerve, close to the optic foramen.
}

to the control of axonal pathways at a complex interchange and also because it probably contributes one step to the process by which the final pattern of the central maps is established.

\section{References}

Akers, R. M., D. F. Mosher, and J. E. Lilien (1981) Promotion of retinal neurite outgrowth by substratum bound fibronectin. Dev. Biol. 86: 179-188.

Bishop, G. H., and M. H. Clare (1955) Organization and distribution of fibers in the optic tract of the cat. J. Comp. Neurol. 183: 603-614.

Bishop, P. O., D. Jereny, and J. W. Lance (1953) The optic nerve. Properties of a central tract. J. Physiol. (Lond.) 163: 503-539.

Brouwer, B., and W. P. C. Zeeman (1926) The projection of the retina in the primary optic neuron in the monkey. Brain 49: 1-35.

Brouwer, B., W. P. C. Zeeman, and A. U. M. Houwer (1923) Experimentellanatomische Untersucchungen uber die Projektion der Retina an die primaren Opticuszentren. Schweiz. Arch. Neurol. 206: 209-226.

Bunt, S. M., and R. D. Lund (1982) Optic fiber arrangements in the visual pathways of I ong-Fvans honded rats. Soc. Neurosci. Abstr. 8: 451.

Cucchiaro, J. (1984) The retinal origin and geniculate termination of the optic pathways of normal and albino ferrets. Ph.D. thesis, University of Chicago, Chicago.

Cucchiaro, J., and R. W. Guillery (1984) The development of the retinogeniculate pathways in normal and abnormal ferrets. Proc. R. Soc. Lond. (Biol.) 223. 141-164.

Cunningham, T. S., J. M. Mohler, and D. L. Giordano (1982) Naturally occurring neuron death in the ganglion cell layer of the neonatal rat: Morphology and evidence for regional correspondence with neuron death in superior colliculus. Dev. Brain Res. 2: 203-215.

Donovan, A. (1967) The nerve fiber composition of the cat optic nerve. J. Anat. 101: 1-11

Easter, S. S., Jr., A. C. Rusoff, and P. E. Kish (1981) The growth and organization of the optic nerve and tract in juvenile and adult goldfish. $J$ Neurosci. 1: 793-811.

Easter, S. S., Jr., B. Bratton, and S. S. Scherer (1984) Growth-related order of the retinal fiber layer in goldfish. J. Neurosci. 1: 2173-2190.

Gaze, R. M., and P. Grant (1978) The diencephalic course of regenerating retinotectal fibers in Xenopus tadpoles. J. Embryol. Exp. Morphol. 44: 201-216

Gaze, R. M., M. J. Keating, A. Ostberg, ansd S. -H. Chung (1979) The relationship between retinal and tectal growth in larval Xenopus: Implications for the development of the retinotectal projection. J. Embryol. Exp. Morphol. 53: 103-142.

Goodrum, J. F., A. D. Toews, and P. Morell (1979) Axonal transport and metabolism of ${ }^{3} \mathrm{H}$-fucose- and ${ }^{35} \mathrm{~S}$-sulfate-labelled macromolecules in the rat visual system. Brain Res. 176: 255-272.

Greiner, J. V., and T. A. Weidman (1980) Histogenesis of the cat retina. Exp. Eye Res. 30: 439-453.

Greiner, J. V., and T. A. Weidman (1981) Histogenesis of the ferret retina. Exp. Eye Res. 33: 315-332.

Guillery, R. W., E. H. Polley, and F. Torrealba (1982) The arrangement of axons according to fiber diameter in the optic tract of the cat. J. Neurosci. 2: 714-721.

Herrick, C. J. (1941) Development of the optic nerves of Amblystoma. J. Comp. Neurol. 74: 473-534.

Herrick, C. J. (1942) Optic and postoptic systems in the brain of Amblystoma tigrinum. J. Comp. Neurol. 77: 191-353

His, W. (1904) Die Entwicklung des Menschlichen Gehirns, p. 28, S. Hirzel, Leipzig.

Hollyfield, J. G. (1968) Differential addition of cells to the retina in Rana pipiens tadpoles. Dev. Biol. 18: 163-179.

Horton, J. C., M. M. Greenwood, and D. H. Hubel (1979) Non-retinotopic arrangement of fibres in cat optic nerve. Nature 282: 720-723.

Hoyt, W. F., and O. Luis (1962) Visual fiber anatomy in the infrageniculate pathway of the primate. Arch. Ophthaimol. 68: 94-106.

Hughes, A., and H. Wässle (1976) The cat optic nerve: Total fibre count and diameter spectrum. J. Comp. Neurol. 169: 171-184.

Jackson, C. A., and F. R. Amthor (1984) Morphology of retinal ganglion cells in the ferret. Invest. Ophthalmol. Vis. Sci. (Suppl.) 25: 204.

Jacobson, M. (1976) Histogenesis of retina in the clawed frog with implications for the pattern of development of retinotectal connections. Brain Res. 103: $541-545$

Jacobson, M. (1977) Mapping the developing retinotectal projection in frog tadpoles by a double label autoradiographic technique. Brain Res. 127 . 55-67.

Johns, P. R. (1977) Growth of the adult goldfish eye. III. Source of the new retinal cells. J. Comp. Neurol. 176: 343-358. 
Karlsson, J. O., and J. Sjöstrand (1971) Synthesis, migration and turnover of protein in retinal ganglion cells. J. Neurochern. 18: 749-767.

Karlsson, J. O., and J. Sjöstrand (1972) Axonal transport of proteins in retinal ganglion cells. Characterization of the transport to the superior colliculus. Brain Res. 47: 185-194.

Kliot, M., and C. J. Shatz (1982) Genesis of different retinal ganglion cell types in the cat. Soc. Neurosci. Abstr. 8: 815.

Krayanek, S., and S. Goldberg (1981) Oriented extracellular channels and axonal guidance in the embryonic chick retina. Dev. Biol. 84: 41-50.

Lashley, K S. (1934) The merchanics of vision. VII. The projection of the retina upon the primary optic center of the rat. J. Comp. Neurol. 59: 341373.

LaVail, J. H., and M. M. LaVail (1974) The retrograde intraaxonal transport of horseradish peroxidase in the chick visual system: A light and electron microscopic study. J. Comp. Neurol. 157: 303-358.

Letourneau, P. C. (1982) Nerve fiber growth and its regulation by extrinsic factors. In Neuronal Development, N. C. Spitzer, ed., pp. 213-254, Plenum Press, New York.

Linden, D. C., K. W. Gullery, and J. Cucchiaro (1981) The dorsal lateral geniculate nucleus of the normal ferret and its postnatal development. J. Comp. Neurol. 203: 189-211.

Mastronarde, D. N. (1984) Organization of the cat's optic tract as assessed by single-axon recordings. J. Comp. Neurol. 227: 14-22.

Mesulam, M.-M. (1984) Principles of horseradish peroxidase neurohistochemistry and their applications for tracing neural pathways-Axonal transport, enzyme histochemistry and light microscopic analysis. In Tracing Neural Connections with Horseradish Peroxidase, M. -M. Mesulam, ed., pp. 1151, John Wiley \& Sons, Ltd., Chichester.

$\mathrm{Ng}$, A. Y. K., and J. Stone (1982) The optic nerve of the cat: Appearance and loss of axons during normal development. Dev. Brain Res. 5: 263271.

Nordlander, R. H., and M. Singer (1982) Morphology and position of growth cones in the developing Xenopus spinal cord. Dev. Brain Res. 4: 181193.

Polley, E. H., C. Walsh, and T. L. Hickey (1981) Neurogenesis in the cat retina; a study using ${ }^{3} \mathrm{H}$-thymidine autoradiography. Soc. Neurosci. Abstr. 7: 672 .

Polyak. S. (1957) The Vertebrate Visual System, H. Kluver, ed., University of Chicago Press, Chicago.

Rager, G. H. (1980) Development of the retinotectal projection in the chicken Adv. Anat. Embryol. Cenl Biol. 63: 1-92.

Rakic, P., and K. P. Riley (1983) Overproduction and elimination of retinal axons in the fetal rhesus monkey. Science 219: 1441-1444.

Ramón y Cajal, S. (1960) Studies on Vertebrate Neurogenesis, L. Guth, transt. Charles C Thomas Publisher, Springfield, IL.

Reh, T. A., E. Pitts, and M. Constantine-Paton (1983) The organization of fibers in the optic nerve of normal and tectum-less Rana pipiens. J. Comp. Neurol. 218: 282-296.

Rogers, A. W. (1979) Techniques of Autoradiography, Elsevier/North-Holland Biomedical Press, Amsterdam.

Rogers, S. L., P. C. Letourneau, S. L. Palm, J. McCarthy, and L. Furcht (1983) Neurite extension by peripheral and central nervous system neurons in response to substratum-bound fibronectin and laminin. Dev. Biol. 98 : 212-220.
Rusoff, A. C. (1984) Paths of axons in the visual system of perciform fish and implications of these paltis for rules governing axonal growth. J. Neurosci. 4: 1414-1428.

Schall, J. D., D. Vitrek, and A. G. Leventhal (1984) Retinal ganglion cell classes in the pigmented terret. Invest. Ophthalmol. Vis. Sci. (Suppl.) 25 204

Scholes, J. H., and A. Maggs (1983) The substrate for optic nerve fiber growth in fish. Soc. Neurosci. Abstr. 9: 761

Schonbach, J., and M. Cuenod (1971) Axoplasmic migration of protein. A light microscopic autoradiographic study in the avian retino-tectal pathway. Exp. Brain Res. 12: 275-282

Scott. T. M., and G. Lazar (1976) An investigation into the hypothesis of shifting neuronal relationships during development. J. Anat. 121: 485-496.

Sengelaub, D. R., and B. L. Finlay (1981) Early removal of one eye reduces normally occurring cell death in the remaining eye. Science 213: 573-574

Shatz, C. J. (1983) The prenatal development of the cat's retinogeniculate pathway. J. Neurosci. 3: 482-499.

Sidman, R. L. (1961) Histogenesis of mouse retina studied with thymidine ${ }^{3} \mathrm{H}$. In The Structure of the Eye, G. K. Smelser, ed., pp. 487-505, Academic Press, Inc., New York.

Sjöstrand, J., J. -O. Karlsson, and C. Marchisio (1973) Axonal transport in growing and mature retinal ganglion cells. Brain Res. 62: 395-397.

Skoff, R. P., and V. Hamburger (1974) Fine structure of dendritic and axonal growth cones in embryonic chick spinal cord. J. Comp. Neurol. 153: 107147.

Taylor, J. S. H., and A. Roberts (1983) The early development of the primary sensory neurons in an amphibian embryo: A scanning electron microscope study. J. Embryol. Exp. Morphol. 75: 49-66.

Torrealba, F., R. W. Guillery, U. Eysel, E. H. Polley, and C. A. Mason (1982) Studies on retinal representations within the cat's optic tract. J. Comp. Neurol. 211: 377-396

Van Crevel, M., and W. J. C. Verhaart (1963) The rate of secondary degeneration in the central nervous system. II. The optic nerve of the cat. J. Anat. 97: 451-464.

Vanegas, H., H. Hollander, and H. Distel (1978) Early stages of uptake and transport of horseradish peroxidase by cortical structures, and its use for the study of local neurons and their processes. J. Comp. Neurol. 177: 193-212.

Walsh, C., and R. W. Guillery (1982) The development of the ferret's optic tract. Invest. Ophthalmol. Vis. Sci. (Suppl.) 22: 46.

Walsh, $C$, and $E$. H. Polley (1985) The topography of ganglion cell production in the cat's retina. J. Neurosci. 5: 741-750.

Walsh, C., E. H. Polley, T. L. Hickey, and R. W. Guillery (1983) Generation of cat retinal ganglion cclls in relation to contral pathways. Naturc 302 : $611-614$

Williams, R. W., and L. M. Chalupa (1983) An analysis of axon caliber within the optic nerve of the cal: Evidence of size groupings and regional organization. J. Neurosci. 3: 1554-1564.

Williams, R. W and P. Rakic (1984a) Axon-axon order is not preserved in the embryonic primate optic nerve. An electron microscopic analysis from serial sections. Invest. Ophthalmol. Vis. Sci. (Suppl.) 25: 125.

Williams, R. W., and P. Rakic (1984b) Form, ultrastructure, and selectivity of growth cones in the developing primate optic nerve: 3-dimensional reconstructions from serial electron micrographs. Soc. Neurosci. Abstr. 10: 373. 